\title{
Passive transfer of immunity in dairy calves with additional consumption of immunoglobulin through colostrum supplement: effects in health and performance
}

\author{
Saúde, desempenho e transferência de imunidade passiva em bezerras com consumo \\ adicional de imunoglobulinas através de suplemento de colostro
}

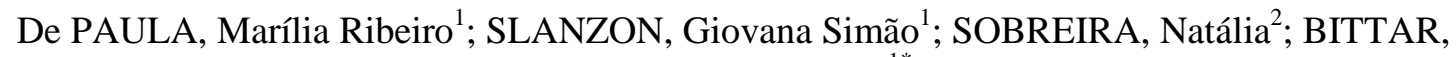 Carla Maris Machado ${ }^{1 *}$}

\author{
${ }^{1}$ Animal Science Department, University of São Paulo, Piracicaba, SP, Brazil. \\ ${ }^{2}$ School of Veterinary Medicine and Animal Science, University of São Paulo, São Paulo, SP, \\ Brazil \\ * Corresponding author: carlabittar@usp.br
}

\section{SUMMARY}

The aim of this study was to evaluate the effects of additional consumption of immuneglobulins associated with high quality colostrum in health and performance of dairy calves. After birth, 80 females were randomly assigned to two treatments: MC) high quality colostrum, supplied in a volume corresponding to $15 \%$ of birth weight; and $\mathrm{MC}+\mathrm{S}$ ) high quality colostrum $(15 \%$ of birth weight $)+$ colostrum supplement. Blood parameters were not affected by the additional supply of immune globulins ( $\mathrm{Ig}$ ) by colostrum supplement feeding. The concentrate and total dry matter intakes were not affected by the administration of colostrum supplementation. The additional intake of Ig through the colostrum supplement did not affect the performance or feed efficiency of calves; however, animals doubled their birth weight at the end of the period, as occurred with MC fed calves. Regarding the health, additional supply of Ig did not affect the number of days with diarrhea, days with fever or medicated days. The additional intake of Ig via colostrum supplement in combination with high quality maternal colostrum have not improved immunity or affected the performance and health of dairy calves.

Keywords: Blood parameters, Immunoglobulin Y, Weight gain

\section{RESUMO}

O objetivo do presente experimento foi avaliar o efeito do consumo adicional de imunoglobulinas através do fornecimento de suplemento de colostro associado a colostro materno de alta qualidade na transferência de imunidade passiva, saúde e desempenho de bezerras da raça Holandesa recém-nascidas. Após o nascimento, 80 fêmeas foram distribuídas aleatoriamente em dois tratamentos: (CM) colostro materno de alta qualidade, fornecido em volume correspondente a $15 \%$ do peso ao nascer $(\mathrm{PN})$; e $(\mathrm{CM}+\mathrm{S})$ colostro materno de alta qualidade $(15 \% \mathrm{PN})+$ suplemento de colostro. Os parâmetros sanguíneos não foram afetados pelo fornecimento adicional de imunoglobulinas (Ig) através da associação de suplemento com colostro materno. $\mathrm{O}$ consumo de concentrado e o consumo total de matéria seca (MS) não foram afetados pela administração do suplemento de colostro. $\mathrm{O}$ consumo adicional de Ig através do fornecimento de suplemento de colostro também não afetou o desempenho e a eficiência alimentar das bezerras, entretanto os animais dobraram o peso ao nascer ao final do experimento, assim como aqueles que receberam $\mathrm{CM}$. Em relação à saúde, o fornecimento adicional de Ig não afetou os dias com diarréia, dias com febre ou dias medicados. $\mathrm{O}$ consumo adicional de Ig através do fornecimento de suplemento de colostro em associação ao colostro materno de alta qualidade não melhorou a imunidade, bem 
Rev. Bras. Saúde Prod. Anim., Salvador, v.20, 01 - 13, e0242019, 2019

como não afetou o desempenho ou a saúde das bezerras.

Palavras-chave: Ganho de peso,

Imunoglobulina Y, Parâmetros sanguíneos 


\section{INTRODUCTION}

Bovine colostrum consists of a mixture of lacteal secretions and components of blood serum, rich in immune globulins (Ig) and other serum proteins, which are accumulate in the mammary gland during the prepartum dry period (Foley \& Otterby, 1978). Dueto the absence of transplacental transfer of antibodies during gestation, the calves are born with undetectable serum levels of immune globulins and they depend on the consumption of colostrum to obtain maternal antibodies. A simple handling factor, such as providing high-quality colostrum in adequate time and volume, ensures a greater chance of survival. Research has shown that the adequate acquisition of passive immunity reduce the incidence of diseases, during a period that the animal will gradually activate its own immune system (Szewczuk et al., 2011).

Colostrum supplements can be considered an important management tool for raising health calves. These products were developed to be used in association with maternal colostrum in order to guarantee the passive immunity transfer in situations where high-quality colostrum is not available (Quigley et al., 2002). Some authors describe the use of supplements to strengthen calves' passive immunity and accelerate the immunity transfer process (Szewczuket al., 2011). In Brazil, commercial colostrum supplements are formulated from chicken eggs, rich in Ig called IgY and vaccinated for certain diseases Some authors argue that when supplementation is associated with maternal colostrum, it allows an increase in the amount of Ig consumed, providing benefits for the animals (Quezada-Tristan et al., 2014).

Provide higher doses of Ig for newborn calves has a direct impact on their immunity system, such as higher levels of circulating Ig, reducing the risk of failure in the passive immunity transfer and consequently lower morbidity and mortality rates (Quigley et al., 2005). Research has shown the benefits of this additional Ig dose, either through higher volumes of colostrum or with supplements (Faber et al., 2005; Quezada-Tristán et al., 2014).

The aim of this study was to evaluate the effect of the additional consumption of immune globulins through the feeding of a colostrum supplement associated with high quality maternal colostrum in the transfer of passive immunity, health and performance of newborn Holstein calves.

\section{MATERIAL AND METHODS}

The study was conducted under the protocol of the Animal Research Ethics Committee of the "Luiz de Queiroz" College of Agriculture (Protocol number 2014-18). The experiment was carried out at Fazenda Colorado, Araras, SP, Brazil, from October 2013 to February 2014. During this period, the average temperature was $25.4^{\circ} \mathrm{C}$ and the average air humidity was $71.1 \%$, according to data collected on the area. Eighty newborn Holstein female calves (birth weight $=39,83 \mathrm{~kg}$ ) were randomly distributed in one of the following treatments 1) high quality maternal colostrum fed in volume corresponding to $15 \%$ birth weight; and 2) high quality maternal colostrum (15\% birthweight) + colostrum supplement (Feedtech Colostrum Supplement, DeLaval, Jaguariúna, SP, Brazil). The colostrum supplement consists of $60 \%$ soybean oil, $20 \%$ whole chicken egg powder (Salmonella Free), dextrose, vitamins and minerals, with $11 \%$ crude protein; $81 \%$ ethereal extract; $0.02 \%$ crude fiber and $5.84 \%$ ashes. 
All births were supervised and all the calves were separated from the cows immediately after calving, avoiding the uncontrolled consumption of colostrum. The cows were milked and the colostrum quality was measured using a colostrometer, a manual brix refractometer (Sper Scientific - Model 300001) and a digital brix refractometer (Hanna Instruments - Model HI 96811). The quality of colostrum was first measured with the colostrotrometer and then with the optical and digital refractometers, always with the colostrum at the same temperature $\left(25^{\circ} \mathrm{C}\right)$. Colostrum was only fed to the calf if its quality was greater than $50 \mathrm{mg}$ Ig / $\mathrm{mL}$ and $21 \%$ brix. When the colostrum produced by the cow exceeded the volume for the calf, exceeding volume was frozen in a colostrum bank for supply in cases of low colostrum production or inadequate quality.

At birth, the females were identified and the navel disinfected with $7 \%$ iodine solution. Calves were weighed in an electronic scale and received colostrum in the volume corresponding to $15 \%$ birth weight, within the first 12 hours, in two meals. In the case of calves that received the colostrum supplement, the product was supplied twice, $15 \mathrm{~mL}$ in the first meal and $15 \mathrm{~mL}$ in the second meal, orally, within the 12-hour period. After this period, the females continued to receive transitional milk until they completed 48 hours, when they started receiving milk.

Blood samples were collected through jugular venipuncture by vacuum tubes without anticoagulant ( $Z$ Serum Sep. Clot Activator VACUETTE Brazil, Campinas, SP, Brazil) at 12 and 24 hours after colostrum feeding. Samples were centrifuged at $2.000 \mathrm{x} g$, for 20 min to obtain the serum, which was used to evaluate serum protein using a protein refractometer (Instrutemp Model ITREF 200). In addition, the excess serum was stored in plastic tubes and stored in a freezer for further analysis of total protein, albumin, $\gamma$ glutamyltransferase $(\gamma-\mathrm{GT})$ and alkaline phosphatase. The determination of the blood parameters was performed using commercial kits (LABTEST Diagnóstica S.A., Lagoa Santa, MG, Brazil), in Automatic System for Biochemistry - SBA-200 Model (CELM, Barueri, SP, Brazil). Total protein concentrations were determined from the enzymatic kit PROTEINAS TOTAIS - Ref .: 99, by end-point spectrophotometry, with an absorbance filter of $540 \mathrm{~nm}$. The albumin concentrations were determined from the enzymatic kit ALBUMIN - Ref .: 19, by means of end-point spectrophotometry, with absorbance filter of $630 \mathrm{~nm}$. For the determination of the concentrations of the $\gamma$ glutamyltransferase enzyme $(\gamma-\mathrm{GT})$, the GAMA kit Liquiform - Ref .: 105 was used, using end-point spectrophotometry, with an absorbance filter of $405 \mathrm{~nm}$. Alkaline phosphatase concentrations were determined using the enzymatic kit FOSFATASE ALCALINA Liquiform - Ref .: 40, by means of end-point spectrophotometry, with an absorbance filter of $590 \mathrm{~nm}$.

After the colostrum-feeding period (48 h), female calves were housed in individual suspended cages with free access to water and starter concentrate. The animals received six liters of pasteurized milk daily from the farm, divided into two meals (7:00 a.m. and 3:00 p.m.). The calves received commercial concentrated feed (Rumileite, Guabi Animal Nutrition), containing $23 \% \mathrm{CP}, 3.5 \%$ EE, $21 \%$ $\mathrm{NDF}$, and the leftovers of the previous day were measured to establish their daily consumption of starter 
concentrate. Weekly, the calves were measured with a scale weight flexible tape for performance estimation (Heinrichs \& Hargrove, 1987), and at 30 and 60 days they were weighed in an electronic scale.

Fecal score evaluation was performed daily as described by Larson et al. (1977), the feces were classified according to their fluidity (1, normal, 2 : soft, 3: aqueous, 4: fluid). Cases of diarrhea were considered when the animals had a score $>2$. In addition, all animals were evaluated for clinical signs of diseases, especially those related to bovine respiratory diseases (BRD) and diarrhea. In the case of the development of any disease, the animals were treated following the recommendations of the veterinarian responsible for the herd. All cases and treatments were recorded. Days with diarrhea were described as the number of days that the animals had a fecal score > 2; days with fever when the animal had temperature was $>39.6^{\circ} \mathrm{C}$, as a cut-point suggested by the farm veterinary to treat animals; and days medicated as the time when antibiotics were administered.

The experimental design was a randomized block. All data were analyzed as repeated measures by the MIXED of SAS (version 9.4, SAS Institute Inc., Cary, NC), according to the model (1).For the analyzes, among the 15 different covariance structures tested, the one that best fit the statistical model was chosen based on the lowest value of the corrected Akaike information criterion (AICC) (Wang \& Goonewardene, 2004). For the purposes of comparison of means, the least squares method (LSMEANS) was used, with a significance level of $5 \%$.

\section{RESULTS AND DISCUSSION}

Total serum protein concentrations, determined by refractometer or enzyme kit, were not affected by the additional supply of Ig through the supplementation of maternal colostrum (P> 0.05; Table 1). On the other hand, there was a significant difference $(P$ $<0.0001)$ in the evaluated time points. The values observed after 24 hours of colostrum feeding were significantly higher than the values observed after 12 hours (Table 1), showing that the Ig absorption continued even after 12 hours of colostrum feeding exclusively or associated with colostrum supplement. 
Table 1 - Serum concentrations of passive immunity indicators in calves receiving maternal colostrum (MC) or maternal colostrum associated with colostrum supplement $(\mathrm{MC}+\mathrm{S})$

\begin{tabular}{|c|c|c|c|c|}
\hline & \multicolumn{4}{|c|}{ Treatments } \\
\hline & MC & $\mathrm{MC}+\mathrm{S}$ & SEM & $P$-value \\
\hline \multicolumn{5}{|c|}{ Total protein, $\mathrm{g} / \mathrm{dl}$, refractometer } \\
\hline 12 hours & $5.49^{\mathrm{B}}$ & $5.63^{\mathrm{B}}$ & 0.18 & 0.5907 \\
\hline 24 hours & $6.69^{\mathrm{A}}$ & $6.58^{\mathrm{A}}$ & 0.15 & 0.6031 \\
\hline Average & 6.09 & 6.10 & 0.14 & 0.9399 \\
\hline \multicolumn{5}{|c|}{ Total protein, $\mathrm{g} / \mathrm{dl}$} \\
\hline 12 hours & $6.28^{\mathrm{B}}$ & $6.55^{\mathrm{B}}$ & 0.33 & 0.5659 \\
\hline 24 hours & $7.50^{\mathrm{A}}$ & $7.15^{\mathrm{A}}$ & 0.22 & 0.2462 \\
\hline Average & 6.90 & 6.85 & 0.21 & 0.8647 \\
\hline \multicolumn{5}{|c|}{ Albumin, $\mathrm{g} / \mathrm{dl}$} \\
\hline 12 hours & 2.02 & 2.18 & 0.08 & 0.1467 \\
\hline 24 hours & 2.19 & 2.17 & 0.03 & 0.5492 \\
\hline Average & 2.11 & 2.18 & 0.04 & 0.2821 \\
\hline \multicolumn{5}{|c|}{ 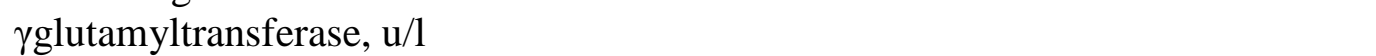 } \\
\hline 12 hours & 858.7 & 799.3 & 91.8 & 0.6492 \\
\hline 24 hours & 868.9 & 896.7 & 62.9 & 0.7569 \\
\hline Average & 863.8 & 848.0 & 63.3 & 0.8605 \\
\hline \multicolumn{5}{|c|}{ Alkalinephosphatase, $\mathrm{u} / \mathrm{l}$} \\
\hline 12 hours & $417.2^{\mathrm{A}}$ & $503.7^{\mathrm{A}}$ & 49.8 & 0.2220 \\
\hline 24 hours & $312.5^{\mathrm{B}}$ & $395.5^{\mathrm{B}}$ & 41.9 & 0.1650 \\
\hline Average & 364.9 & 449.6 & 41.9 & 0.1565 \\
\hline
\end{tabular}

SEM: Standard error of the mean.

${ }_{\mathrm{A}, \mathrm{B}}$ Different letters indicate statistical difference $(\mathrm{P}<0.0001)$.

The values reached within 12 hours of colostrum feeding would be enough to guarantee the transfer of immunity to the animals, since McGuirk \& Collins (2004) considered values of serum protein higher than $5.5 \mathrm{~g} / \mathrm{dL}$ as a successful transfer of passive immunity. Williams et al. (2014) fed additional Ig (172 vs $256 \mathrm{~g}$ ) to calves through higher volume of colostrum ( 2 vs $4 \mathrm{~L}$ ) and observed that the animals, which ingested lower volume of colostrum and consequently lower amount of Ig, had significantly lower values of serum protein. However, this did not affect the health of the animals, since the amount offered exceeded the $100 \mathrm{~g}$ of $\mathrm{IgG}$ recommended in the literature.
In a study providing additional Ig through a colostrum supplement associated with high-quality colostrum, contrasting the present study, QuezadaTristán et al. (2014) observed higher values of total serum protein for calves that received maternal colostrum associated with Ig from chicken eggs. The authors suggest that the IgY from the yolks was responsible for the higher values of serum protein. In addition, there is a positive correlation between total protein and serum $\mathrm{IgG}$ concentrations. According to the authors, the supply of this additional Ig was beneficial when fed with colostrum. Serum albumin concentrations were not affected by the colostrums supplementation $(\mathrm{P}=0.2821)$ and were 
not altered by the time of data collection after colostrum feeding $(\mathrm{P}>0.05$; Table 1). The values observed for albumin concentration agrees with the values reported by Mohri et al. (2007) for calves at this stage. According to the authors, these concentrations increase up to 3 months of age, when they stabilize and are similar to those observed in adult animals. Rauprich et al. (2000) suggested that serum albumin tends to decrease within the first 8 hours of life and from this period, it begins to increase, being correlated with colostrum supply and liver synthesis.

The concentration of $\gamma$ glutamyltransferase $(\gamma-\mathrm{GT})$ were not affected by the additional supply of Ig via supplement $(\mathrm{P}=0.8605$; Table 1$)$ and were not affected by collection time after colostrum delivery $(\mathrm{P}>0.05)$. The lack in differences between 12 and $24 \mathrm{~h}$ may have occurred as a response to the second colostrum meal. The concentration of $\gamma$-glutamyltransferase $(\gamma-\mathrm{GT})$ correlates with the data presented by Feitosa et al. (2001), who reported values of $840.55 \mathrm{U} / \mathrm{L}$ for calves with 24 hours after birth. Animals with 24 hours of life should present $\gamma$-GT values higher than $200 \mathrm{U} /$ $\mathrm{L}$ and animals with values lower than $50 \mathrm{U} / \mathrm{L}$, within the first two weeks of age, are considered with failure in the process of passive immunity transfer (Weaver et al., 2000). Blum \& Hammon (2000) reported that $\gamma$-GT concentrations in colostrum are higher than 30,000 U / L. Rauprich et al. (2000) report that the activity of this enzyme increases after the first meal in response to the colostrum absorption of $\gamma$-GT and tends to decrease from the second to the seventh day of calves' life. However, it is not known yet the importance of this post- prandial increase (Blum \& Hammon, 2000). Weaver et al. (2000) reported that serum $\gamma$-GT can be used to confirm colostrum ingestion but does not allow an accurate assessment of serum $\mathrm{IgG}$ concentration in animals.

The supply of additional Ig through the association of maternal colostrum and colostrum supplement did not affect Alkaline phosphatase concentrations ( $\mathrm{P}$ $=0.1565)$. However, there was an effect of the evaluation period (Table 1). The enzymatic concentrations were significantly lower $(\mathrm{P}<0.05)$ at 24 hours of life, demonstrating that at this time the concentrations were already decreasing. Alkaline phosphatase as well as $\gamma$-GT can be used to estimate passive immunity transfer, although it has been less studied (Zanker et al., 2001). Mohri et al. (2007) also reported lower rates up to 28 days of life, when a new increase in concentrations occurs due to endogenous production. According to the authors, this enhance in the first day of life is related to the absorption of colostrum, which has concentrations of this enzyme higher than 1,000 U / L (Blum \& Hammon, 2000), raging according to the amount and time of ingestion.

Starter intake and total intake were not affected by administration of colostrum supplement ( $\mathrm{P}>0.05$; Table 2), but presented an age effect in both parameters $(\mathrm{P}<0.0001)$. Starter intake increased over the weeks (Figure 1), but at the end of the study, the calves were not consuming the adequate amounts of feed recommended by the literature to be weaned. 
Table 2 - Consumption and performance of calves receiving maternal colostrum (MC) or maternal colostrum associated with colostrum supplement $(\mathrm{MC}+\mathrm{S})$

\begin{tabular}{|c|c|c|c|c|c|c|}
\hline & \multicolumn{3}{|c|}{ Treatments } & \multicolumn{3}{|c|}{ P-value } \\
\hline & $\mathrm{MC}$ & $\mathrm{MC}+\mathrm{S}$ & SEM & $\mathrm{T}$ & A & TxA \\
\hline \multicolumn{7}{|l|}{ Intake, g MS/d } \\
\hline Starter intake & 249.9 & 269.3 & 21.9 & 0.5325 & 0.0001 & 0.0842 \\
\hline Total $^{(1)}$ & 999.9 & 1019.3 & 21.9 & 0.5325 & 0.0001 & 0.0842 \\
\hline \multicolumn{7}{|l|}{ Bodyweight, $\mathrm{kg}$} \\
\hline At birth & 40.3 & 39.3 & 1.34 & 0.6069 & - & - \\
\hline At 28 days & 57.0 & 55.9 & 1.34 & 0.5770 & - & - \\
\hline At 56 days & 81.6 & 81.9 & 1.34 & 0.8938 & - & - \\
\hline Average total period & 59.6 & 59.0 & 1.24 & 0.7359 & 0.0001 & 0.4820 \\
\hline \multicolumn{7}{|l|}{ Weightgain } \\
\hline 0 to $28 \mathrm{~d}, \mathrm{~g} / \mathrm{d}$ & 556.1 & 553.4 & 27.5 & 0.9454 & - & - \\
\hline 28 to $56 \mathrm{~d}, \mathrm{~g} / \mathrm{d}$ & 839.0 & 886.0 & 27.5 & 0.2286 & - & - \\
\hline 0 to $56 \mathrm{~d}, \mathrm{~g} / \mathrm{d}$ & 697.6 & 719.7 & 22.1 & 0.4799 & 0.0001 & 0.2868 \\
\hline Heart girth gain, $\mathrm{cm}$ & 89.1 & 89.1 & 0.61 & 0.9447 & 0.0001 & 0.3769 \\
\hline Hip width gain, $\mathrm{cm}$ & 26.6 & 26.7 & 0.10 & 0.8903 & 0.0001 & 0.9554 \\
\hline $\mathrm{Kg}$ of gain/kg MS intake & 0.833 & 0.861 & 0.02 & 0.3497 & 0.0001 & 0.2182 \\
\hline
\end{tabular}

T: treatment effect, A: age effect, TxA: interaction Treatment $\mathrm{x}$ age.

SEM: Standard error of the mean.

${ }^{1}$ Considering whole milk with $12.5 \%$ of solids.

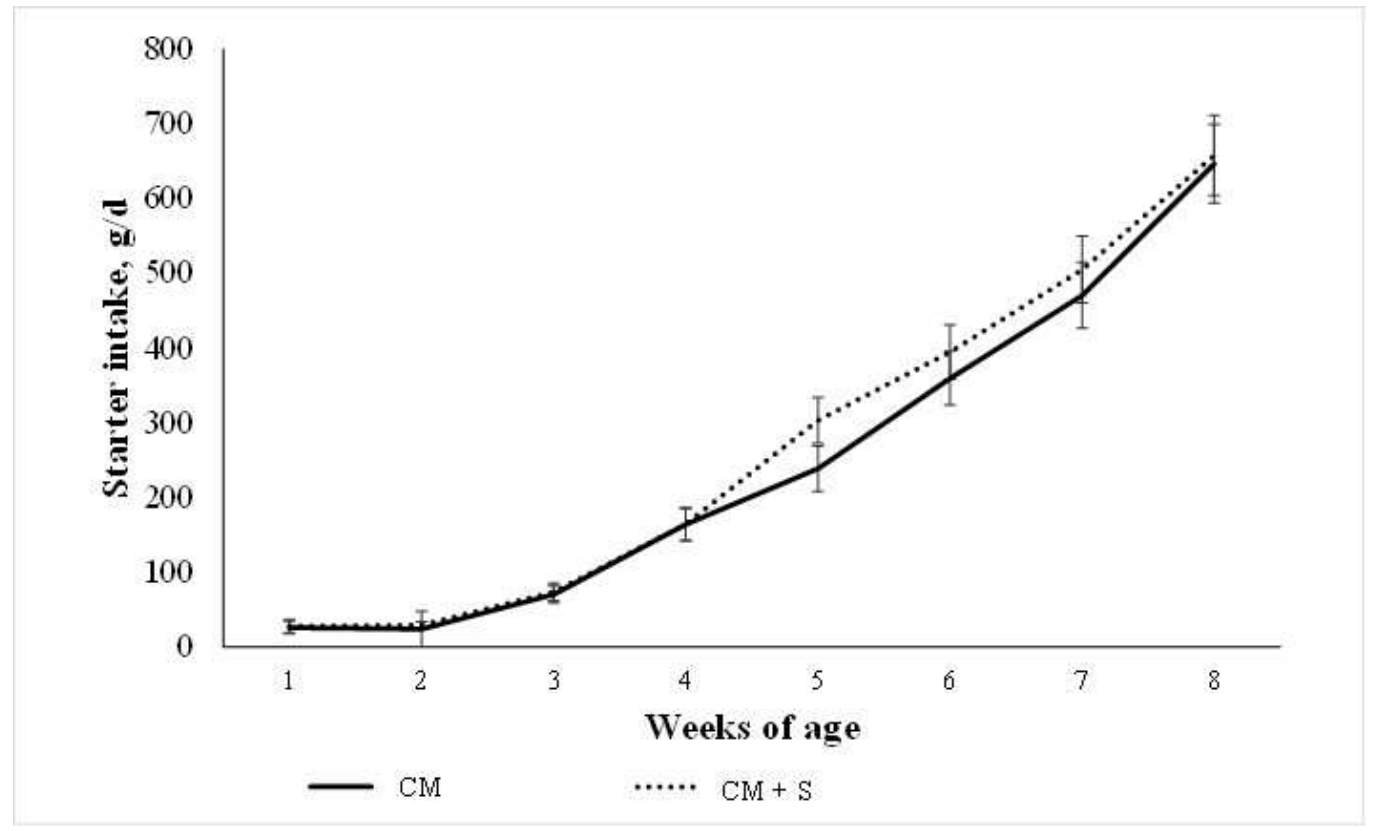

Figure 1 - Starter intake (g DM / d) of calves receiving maternal colostrum or maternal colostrum + colostrum supplement 
A calf is prepared to be weaned when it is consuming at least $1 \mathrm{~kg}$ of starter concentrate per day (Stamey et al., 2012). However, in the commercial farm where the present study occurred, the weaning process occurred around the tenth week of calves' life, guaranteeing enough time for the animals to increase their consumption. Hopkins \& Quigley (1997) fed colostrum supplement associated with high-quality maternal colostrum and followed the performance of dairy calves up to their 56 days of life, receiving $4 \mathrm{~L} / \mathrm{d}$ of liquid diet. The authors observed that the additional Ig, similar to what occurred in the present study, did not affect animals' consumption. However, the authors reported an average intake of $400 \mathrm{~g} /$ day, levels higher to those reported in the present study. This factor can be explained by the lower amount of liquid diet ingested by the calves. Still, according to the authors, the total dry matter intake did not differ between treatments and was on average $917 \mathrm{~g} / \mathrm{d}$. The additional consumption of $\mathrm{Ig}$ through the colostrum supplement also did not affect the average body weight $(\mathrm{P}=0.7359)$ or the average daily weight gain $(\mathrm{P}=0.4799)$. There was an age effect ( $\mathrm{P}<0.0001)$ for these two parameters, with values increasing over the weeks (Table 2). The animals started the experiment with an average body weight of $40 \mathrm{~kg}$ and finish the experiment, at 56 days, with body weight higher than $80 \mathrm{~kg}$, which means that the animals doubled their birth weight in this period, as recommended in the literature (Van Amburgh \& Drackley, 2005). Animals receiving maternal colostrum or an additional $\mathrm{Ig}$ associated with maternal colostrum, presented similar gains in the present study (Szewczuk et al., 2011). Faber et al. (2005) reported higher weight gains and higher growth rates for heifers who received additional Ig through increased colostrum feeding. In addition, the authors observed higher milk production during the first and second lactations of these animals, in response to the increased supply of colostrum.

There was no effect of supplementation on the heart girth $(\mathrm{P}=0.9447)$ and in the hip width $(\mathrm{P}=0.8903$; Table 2$)$. Other authors also did not report differences in body growth of calves receiving $250 \mathrm{~g}$ of $\mathrm{IgG}$ via maternal colostrum or colostrum substitute (Jones et al., 2004). Wilson et al. (1997) performed a survey in dairy herds and observed similar values of hip width, however the hear girth was higher than those found in the present study.

Feeding efficiency was not affected by administration of colostrum supplement in combination with high-quality colostrum ( $\mathrm{P}=0.3449$; Table 2). Jones et al. (2004) observed higher feed efficiency and a tendency to gain more weight during the first weeks of life in calves receiving $250 \mathrm{~g}$ of $\mathrm{IgG}$ via maternal colostrum when compared to animals receiving the same dose via colostrum substitute. However, no difference was observed when the animals were weaned.

In the evaluation of the fecal score, the occurrence of diarrhea was considered when the score was higher than 2 , which occurred only during the second week of calves' life (Figure 2). 


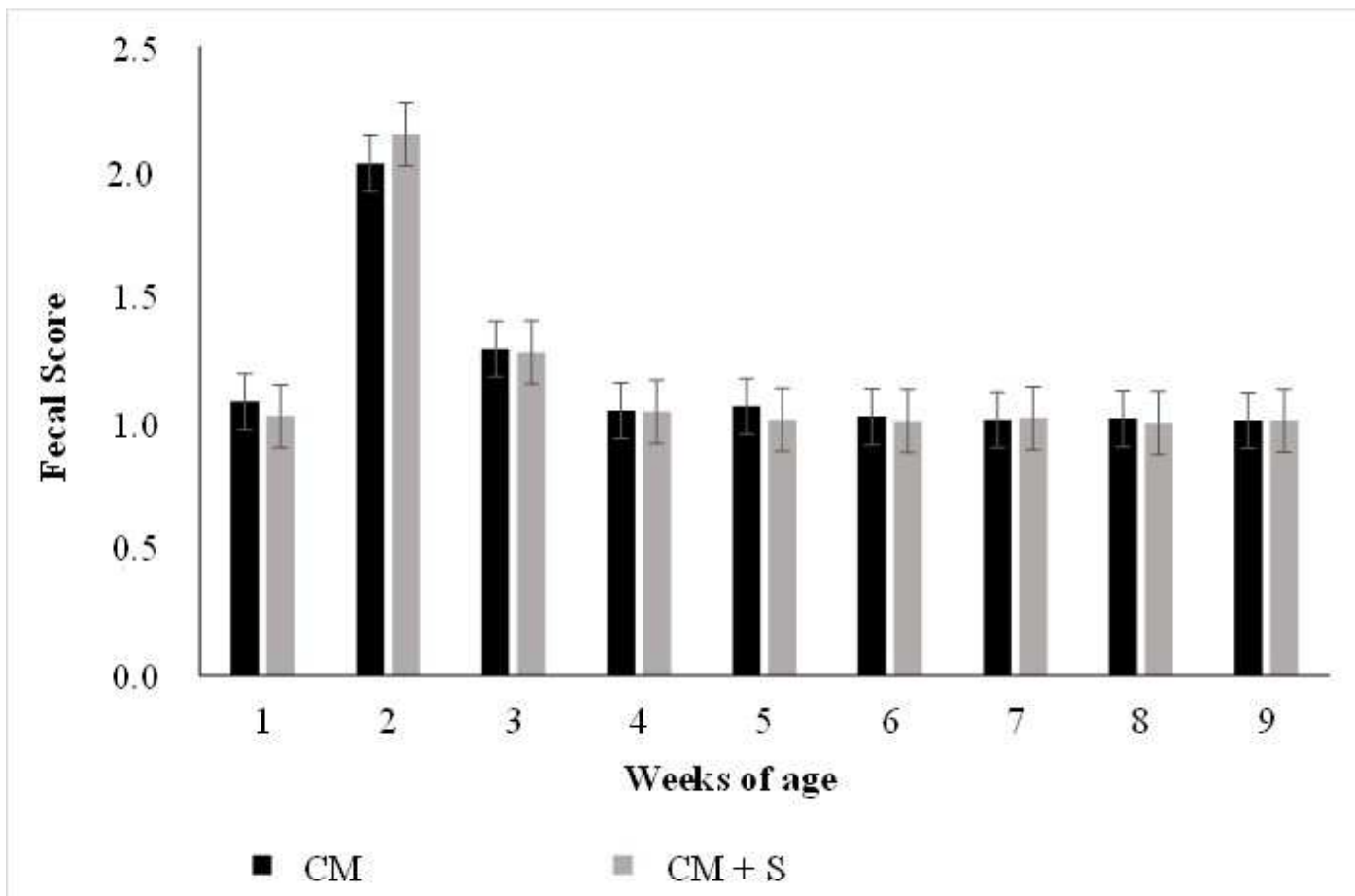

Figure 2 - Fecal score of calves that received maternal colostrum or maternal colostrum + colostrum supplement

The fecal score was not affected $(\mathrm{P}=0.8398)$ by supplying the colostrum supplement in association with high-quality colostrum. Regarding health, additional Ig supply did not affect days with diarrhea $(\mathrm{P}=0.4907)$, days with fever $(\mathrm{P}=0.2446)$ or days medicated $(\mathrm{P}$ $=0.9567$; Table 3).It was expected that the additional supply of Ig would improve the animals' immunity system and would reduce cases of diarrhea. However, the fecal score was not affected by supplying the colostrum supplement in association with highquality colostrum. Meganck et al. (2015) provided colostrum of different qualities for calves in order to obtain an average intake of $200 \mathrm{~g}$ of $\mathrm{IgG}$ in the first 12 hours of life and did not observe differences in the percentage of calves with diarrhea. Williams et al. (2014) provided additional Ig to calves through higher volume of colostrum ( 2 vs $4 \mathrm{~L}$, 172 vs $256 \mathrm{~g}$ Ig) and observed no difference between treatments in the occurrence of diseases, such as diarrhea and pneumonia. However, they suggest that the data should be observed with caution, since there are many external factors during the calves' rearing.

Table 3 - Health parameters of calves receiving maternal colostrum (MC) or maternal colostrum + colostrum supplement $(\mathrm{MC}+\mathrm{S})$

\begin{tabular}{lllll}
\hline & \multicolumn{2}{l}{ Treatments } & \\
\cline { 2 - 5 } & $\mathrm{MC}$ & $\mathrm{MC}+\mathrm{S}$ & $\mathrm{SEM}$ & P value \\
\hline Health & & & & \\
Dayswith diarrhea & 2.80 & 3.07 & 0.28 & 0.4907 \\
Dayswithfever & 0.93 & 0.62 & 0.19 & 0.2446 \\
Daysofmedication & 2.80 & 2.85 & 0.60 & 0.9567 \\
\hline
\end{tabular}


SEM: Standard error of the mean.

In both treatments, $97 \%$ of the animals became ill for at least one day. Twenty calves that became ill from maternal colostrum group received medication, which represents that $50 \%$ of the calves needed to be treated. In the maternal colostrum group associated with colostrum supplement, $43.5 \%$ of the animals were medicated. Szewczuk et al. (2011) reported that $15 \%$ of the animals that received only high-quality maternal colostrum presented respiratory diseases, whereas no case were observed in the group that received high-quality maternal colostrum associated with colostrum supplement.

In the present study, the additional supply of Ig occurred during the time that the $\mathrm{Ig}$ absorption is still present, however, studies indicates that benefits from additional supply may occur after this period. Vega et al. (2011) provided an egg-based supplement from vaccinated hens containing IgY during 14 days, after feeding colostrum for the calves. The authors reported that $20 \%$ of the supplemented animals presented diarrhea, compared to $100 \%$ of the group that did not received the supplementation. According to the authors, this additional Ig, besides improving the weight gain of the animals, protected them during the first 14 days of life, the critical phase of higher incidence of diarrhea. However, this action of prolonged supply is only local, acting directly on the calves' intestines, whereas the feeding of higher doses in the first hours has the main function to increase the systemic immunity.

Swan et al. (2007) reported 1.7 days of medication use for animals receiving maternal colostrum and 2.0 days of medication use for animals receiving colostrum substitute, similar to the one found in the present study. Already, Santoro et al. (2004) reported an average of 6 days of medication for animals receiving maternal colostrum and 11 days of antimicrobial use for animals receiving colostrum supplementation.

Both groups had a $2.5 \%$ mortality rate, values lower than those were observed by Quigley et al. (2000), with rates of $16.7 \%$ mortality in animals receiving different doses of $\operatorname{IgG}$ from maternal colostrum $(156 \mathrm{~g}$ of $\mathrm{IgG})$ or colostrum substitute (90g of $\mathrm{IgG})$. Arthington et al. (2000) tested a colostrum substitute (90g of $\mathrm{IgG}$ ) in comparison to a maternal colostrum (100g of $\mathrm{IgG}$ ) and the authors observed mortality rates above $11 \%$ in all treatments, values higher than those found in the present study. However, the percentage of animals ill reported by some researchers (Arthington et al., 2000; Swan et al., 2007) are lower than those described in this present study, affecting less than $60 \%$ of the calves.

\section{FINAL CONSIDERATION}

The additional consumption of Ig via colostrum supplement in combination with high-quality maternal colostrum did not improve calves' performance or health. The consumption of maternal colostrum with high concentrations of $\mathrm{Ig}$, at the rate of $15 \%$ of the newborn's weight right after birth, was enough to ensure a satisfactory passive immunity transfer, with no benefits from the additional supply of $\mathrm{Ig}$ via colostrum supplement.

\section{ACKNOWLEDGEMENTS}


The authors wish to express their appreciation for the support provided by the National Council for Scientific and Technological Development (CNPq) as research grant and scholarship. Authors also are grateful to the Colorado Dairy Farm.

\section{REFERENCES}

ARTHINGTON, J.D.; CATTELL, M. B.; QUIGLEY III, J.D. Effect of dietary IgG source (colostrum, serum, or milkderived supplement) on the efficiency of Ig absorption in newborn Holstein calves. Journal of Dairy Science, v. 83, p. 1463-1467, 2000.

BLUM, J.W.; HAMMON, H. Colostrum effects on the gastrointestinal tract, and on nutritional, endocrine and metabolic parameters in neonatal calves. Livestock Production Science, v. 66, p. 151-159, 2000.

FABER, S.N.; FABER, N.E.; MCCAULEY, T.C.; AX, R.L. Effects of colostrum ingestion on lactational performance. The Professional Animal Scientist, v. 21, p. 420-425, 2005.

FEITOSA, F.L.F.; BIRGEL, E.H.; MIROLA, R.M.S.; PERRI, S.H.V. Diagnóstico de falha de transferência de imunidade passiva em bezerros através da determinação de proteína total e de suas frações eletroforéticas, $\mathrm{IgG}$ e $\mathrm{M} \mathrm{e}$ da atividade da gamaglutamiltransferase no soro sanguíneo. Ciência Rural, v. 31, p. 251- 255, 2001.

FOLEY, J.A.; OTTERBY, D.E. Availability, storage, treatment, composition, and feeding value of surplus colostrum: a review. Journal of Dairy Science, v. 61, p. 1033-1060, 1978.
HEINRICHS, A.J.; HARGROVE, G.L. Standards of weight and height for Holstein heifers. Journal of Dairy Science, v. 70, p. 653-660, 1987.

HOPKINS, B.A.; QUIGLEY, JD. Effects of method of colostrum feeding and colostrum supplementation on concentrations of immunoglobulin $\mathrm{G}$ in the serum of neonatal calves. Journal of Dairy Science, v. 80, p. 979-983, 1997.

JONES, C.M.; JAMES, R.E.; QUIGLEY III, J.D.; McGILLIARD, M.L. Influence of pooled colostrum or colostrum replacement on igg and evaluation of animal plasma in milk replacer. Journal of Dairy Science, v. 87, p. 1806-1814, 2004.

LARSON, L.L.; OWEN, F.G.; ALBRIGHT, J.L.; APPLEMAN, R.D.; LAMB, R.C.; MULLER, L.D.

Guidelines toward more uniformity in measuring and reporting calf experimental data. Journal of Dairy Science, v. 60, p. 989-991, 1977.

McGUIRK, S.M.; COLLINS M. Managing the production, storage and delivery of colostrum. Veterinarian Clinical North American Food Animal Practice, v. 20, n. 3, p. 593603, 2004.

MEGANCK, V.; HOFLACK, G.; PIEPERS, S.; OPSOMER, G.

Evaluation of a protocol to reduce the incidence of neonatal calf diarrhea on dairy herds. Preventive Veterinary Medicine, v. 118, p. 64-70, 2015.

MOHRI, M.; SHARIFI, K.; EIDI, S. Hematology and serum biochemistry of Holstein dairy calves: age related changes and comparison with blood composition in adults. Research in 
Veterinary Science, v. 83, p. 30-39, 2007.

QUEZADA-TRISTÁN, T.; GARCÍAFLOR, V.L.; ORTIZ-MARTÍNEZ, R.; ARREDONDO-FIGUEROA, J.L.; MEDINA-ESPARZA, L.E.; VALDIVIA-FLORES, A.G.; MONTOYA-NAVARRETE, A.L. Biochemical parameters in the blood of Holstein calves given immunoglobulin Y-supplemented colostrums. BMC Veterinary Research, v. 10, p. 159165, 2014.

QUIGLEY III, J.D.; FRENCH, P; JAMES, E. Short communication: effect of $\mathrm{pH}$ on absorption of immunoglobulin $\mathrm{G}$ in neonatal calves. Journal of Dairy Science, v. 83, p. 1853-1855, 2000.

QUIGLEY III, J.D.; KOST, C.J.; WOLFE, T.M. Absorption of protein and $\mathrm{IgG}$ in calves fed a colostrum supplement or replacer. Journal of Dairy Science, v. 85, p. 1243-1248, 2002.

QUIGLEY III, J.D.; HAMMER, C.J.; RUSSELL, L.E.; POLO, J. Nutrient sources for liquid feeding of calves. In: GARNSWORTHY, P.C. Passive immunity in newborn calves. Nottingham University Press, 2005. chap. 8 , p. 135-157.

RAUPRICH, A.B.; HAMMON, H.M.; BLUM, J.W. Influence of feeding different amounts of first colostrum on metabolic, endocrine, and health status and on growth performance in neonatal calves. Journal of Animal Science, v. 78, p. 896-908, 2000.

SANTORO, H.M.; ERICKSON, P.S.; WHITEHOUSE, N.L.; MCLAUGHLIN, A.M.; SCHWAB, C.G.; QUIGLEY III, J.D. Evaluation of a colostrum supplement, with or without trypsin inhibitor, and an egg protein milk replacer for dairy calves. Journal of Dairy Science, v. 87, p. 1739-1746, 2004.

SAS INSTITUTE.Base SAS ${ }^{\circledR} \mathbf{9 . 4}$ procedure user's guide: statistical procedures. $3^{\text {rd }}$ ed. Cary, 2013. 482 p.

STAMEY, J.A.; JANOVICK, N.A.; KERTZ, A.F.; DRACKLEY, J.K. Influence of concentrate protein content on growth of dairy calves in an enhanced early nutrition program. Journal of Dairy Science, v. 95, p. 3327-3336, 2012.

SWAN, H.; GODDEN, S.; BEY, R.; WELLS, S.; FETROW, J.; CHESTERJONES, H. Passive transfer of immunoglobulin $\mathrm{g}$ and pre weaning health in Holstein calves fed a commercial colostrum replacer. Journal of Dairy Sciencev. 90, p. 3857-3866, 2007.

SZEWCZUK, M.; CZERNIAWSKAPIATKOWSKA, E.; PALEWSKI, S.The effect of colostral supplement on the serum protein fractions, health status and growth of calves. Archiv fur Tierzucht, v. 54, p. 115-126, 2011.

VAN AMBURGH, M.; DRACKLEY, J. Current perspectives on the energy and protein requirements of the preweaned calf. In: GARNSWORTHY, P.C. (Ed.). Calf and heifer rearing. Nottingham University Press, 2005. chap. 5, p. 67-82.

VEGA, C; BOK, M; CHACANA, P; SAIF, L; FERNANDEZ, F; PARREÑO, V. Egg yolk IgY: protection against rotavirus induced diarrhea and modulatory effect on the systemic and mucosal antibody responses in newborn calves. 
Veterinary Immunology and

Immunopathology, v. 142, p. 156-169,

2011 .

WANG, Z.; GOONEWARDENE, L.A.

The use of MIXED models in the analysis of animal experiments with repeated measures data. Canadian Journal of Animal Science, v. 84, p. 1-11, 2004.

WEAVER, D.M.; TYLER, J.W.;

VANMETRE, D.C.; HOSTETLER, D.E.; BARRINGTON, G.M. Passive transfer of colostral immunoglobulins in calves. Journal of Veterinary Internal Medicine, v. 14, p. 569-577, 2000.

WILLIAMS, D.R.; PITHUA, P.; GARCIA, A.; CHAMPAGNE, J.; HAINES, D.M.; ALY, S.S. Effect of three colostrum diets on passive transfer of immunity and pre weaning health in calves on a California dairy following colostrum management training. Veterinary Medicine International, v. 2014, p. 1-9, 2014.

WILSON, L.L.; EGAN, C.L.; TEROSKY, T.L. Body measurements and body weights of special-fed Holstein veal calves. Journal of Dairy Science, v. 80, p. 3077-3082, 1997.

ZANKER I.A.; HAMMON H.M.; BLUM J.W. Activities of $\gamma$ glutamyltransferase, alkaline phosphatase, aspartate-aminotransferase in colostrum, milk, blood plasma of calves fed first colostrum at $0 \pm 2,6 \pm 7$, $12 \pm 13,24 \pm 25 \mathrm{~h}$ after birth. Journal of Veterinary Medicine Association, Physiology and Pathology Clinical Medicine, v. 48, p.179-185, 2001. 